\title{
Study of corrosion behavior of carbon and low-alloy steels in $\mathrm{CO}_{2}$-containing environments
}

\author{
Irina Kostitsyna ${ }^{1 *}$, Aleksey Shakhmatov ${ }^{2}$, and Artem Davydov ${ }^{2}$ \\ ${ }^{1}$ RN-BashNIPIneft, 450006 Ufa, Russia \\ ${ }^{2}$ St. Petersburg Polytechnical University, R\&D center Weatherford-Polytechnic, 195251 St. Petersburg, Russia
}

\begin{abstract}
Carbon and low-alloy steels, which constitute the main volume of pipe production, are unstable to the action of aggressive mineralized oil fields environments, which are often in the late stage of development. Recently, attempts have been made to use steels with an economical alloying of chromium up to $0.5 \%$ in $\mathrm{CO}_{2}$-containing media without application of the additional measures against corrosion. The corrosion behaviour of carbon and low-alloy steels with a chromium content of up to $0.5 \%$ in $\mathrm{CO}_{2}$ containing environments was investigated by electrochemical and metallographic studies. The results show that the addition of $0.5 \mathrm{wt} \% \mathrm{Cr}$ could not effectively improve the corrosion resistance of the low-Cr alloy steel in $\mathrm{CO}_{2}$-containing environments.
\end{abstract}

\section{Introduction}

Corrosion remains a major operational obstruction to successful hydrocarbon production, and its optimum control and management is regarded necessary for the cost-effective design of facilities and their safe operations [1]. Carbon dioxide $\left(\mathrm{CO}_{2}\right)$ is a constant component in produced water of almost any oil field. Typical corrosive damage on internal surfaces of pipelines caused by $\mathrm{CO}_{2}$-corrosion is shown in Fig.1.

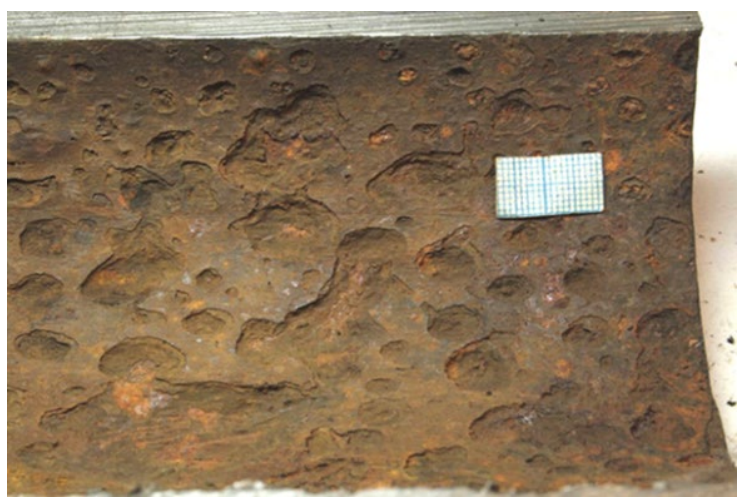

Fig. 1. A typical example of corrosion damage on internal surfaces of pipeline transporting $\mathrm{CO}_{2}$-containing fluids

The industry continues to lean heavily on the extended use of carbon and low-alloy steels, which are readily available in the volumes required and are able to meet many of the mechanical, structural, fabrication, and cost requirements. Their technology is well developed, and they represent an economical materials choice for many applications. However, a key issue for their effective use is their poor general and $\mathrm{CO}_{2}$ corrosion performance. Given the conditions associated with oil and gas production and transportation, corrosion must always be seen as a potential risk. The risk becomes real once an aqueous phase is present and is able to contact the steel, providing a ready electrolyte for the corrosion reaction to occur.

In recent years, there has been an attempt to use low$\mathrm{Cr}$ alloy steel $(0.5 \%-3 \% \mathrm{Cr})$ in $\mathrm{CO}_{2}$ environments without inhibitor injection because adding $\mathrm{Cr}$ to low alloy steel could enhance corrosion resistance [2-4]. It has been reported that the addition of $\mathrm{Cr}$ contributes to the enrichment of $\mathrm{Cr}$ in the corrosion products, which causes the corrosion product layers to be more protective. In addition, an increase in $\mathrm{Cr}$ content could lower both the uniform corrosion rate and susceptibility to localized corrosion in $\mathrm{CO}_{2}$ environments. While some authors have reported the beneficial effects of chromium additions, there is not yet a consensus on the optimum amount of $\mathrm{Cr}$ in the steel structure [1].

The objective of the present study was to evaluate the effect of $\mathrm{Cr}$ content up to $0.5 \mathrm{wt} . \%$ on the corrosion behavior of carbon and low alloy steels under different combinations of $\mathrm{pH}$ and temperature.

\section{Experimental}

\subsection{Material}

The test specimens with different alloying systems were selected from steels, serially used to produce oil and gas pipes. The steels used in this study are melted in electric arc furnaces with following ladle refining and final aluminium deoxidation and calcium treatment. All materials were analysed for chemical composition using

\footnotetext{
* Corresponding author: KostitsynaIV@bashneft.ru
} 
atomic emission spectroscopy. Table 1 shows chemical compositions of steels used in the present study.

Table 1. Chemical compositions of steels

\begin{tabular}{|c|c|c|c|c|c|c|c|}
\hline Steel & $\mathbf{C}$ & $\mathbf{S i}$ & $\mathbf{M n}$ & $\mathbf{P}$ & $\mathbf{S}$ & $\mathbf{C r}$ & $\mathbf{M o}$ \\
\hline $\begin{array}{c}0.20 \mathrm{C}-\mathrm{Mn} \\
\text { (As rolled) }\end{array}$ & 0.18 & 0.23 & 0.51 & 0.009 & 0.015 & 0.08 & 0.01 \\
\hline $0.20 \mathrm{C}-\mathrm{Mn}$ & 0.19 & 0.22 & 0.54 & 0.009 & 0.003 & 0.08 & 0.02 \\
\hline $0.15 \mathrm{C}-0.5 \mathrm{Cr}$ & 0.15 & 0.23 & 0.53 & 0.008 & 0.002 & 0.64 & 0.01 \\
\hline $\begin{array}{c}0.10 \mathrm{C}-0.5 \mathrm{Cr}- \\
0.2 \mathrm{Mo}\end{array}$ & 0.11 & 0.38 & 0.56 & 0.008 & 0.005 & 0.60 & 0.18 \\
\hline
\end{tabular}

According to Table 1 following steels samples were investigated: (1) C-Mn steel in as rolled condition, (2) C$\mathrm{Mn}$ steel, (3) C-Mn-0.5Cr steel with 0.64 wt. \% $\mathrm{Cr}$ addition and (4) C-0.5Cr-Mo steel with the relatively lowest carbon content and $0.60 \mathrm{wt} . \% \mathrm{Cr}$ and 0.18 wt. $\%$ Mo additions. Last three steels were heat treated according to commercial production routes in order to obtain microstructures condition.

\subsection{Electrochemical corrosion tests}

The flat $\approx 0.80 \mathrm{~cm}^{2}$ specimens were used for static electrochemical corrosion tests. Specimens were sequentially ground with 180, 400, and then 600 grit silicon carbide (SiC) paper with following cleaning, degreasing and drying. The test solution was prepared from deionized water with $5 \mathrm{wt} . \% \mathrm{NaCl}$. There were two types of solution regarding $\mathrm{pH}$ range that were used at different temperatures: 20,40 and $60^{\circ} \mathrm{C}$. Table 2 represents tests conditions. The $\mathrm{pH}$ range information will be used as the test solution description in results and discussion chapter.

Table 2. Corrosion electrochemical test conditions

\begin{tabular}{|c|c|c|}
\hline Solution & $\begin{array}{c}\text { Temperatures, } \\
{ }^{\circ} \mathrm{C}\end{array}$ & $\begin{array}{c}\mathrm{pH} \\
\text { range }\end{array}$ \\
\hline $\begin{array}{c}1.5 \mathrm{~g} / \mathrm{L} \mathrm{NaHCO} 3 \text { buffer, } \\
5 \text { wt. } \% \mathrm{NaCl}_{\text {static, }} \\
\text { deaerated, } \mathrm{CO}_{2} \text { saturated }\end{array}$ & $20 ; 40 ; 60$ & $5.6-6.0$ \\
\hline $\begin{array}{c}5 \text { wt. } \% \mathrm{NaCl}_{\text {static, }} \\
\text { deaerated } \mathrm{CO}_{2} \text { saturated }\end{array}$ & $20 ; 40 ; 60$ & $3.8-4.2$ \\
\hline
\end{tabular}

The solution was initially deaerated by 1 hour nitrogen bubbling. Corrosion tests were performed in a $300 \mathrm{~mL}$ cell under atmospheric $\mathrm{CO}_{2}$ pressure. The cell setup consisted of: (1) three-electrode corrosion cell: Pt counter electrode, $\mathrm{Ag} / \mathrm{AgCl}$ reference electrode, working electrode); (2) oil thermostat system; (3) $\mathrm{CO}_{2}$ gas supply set (Fig. 2).

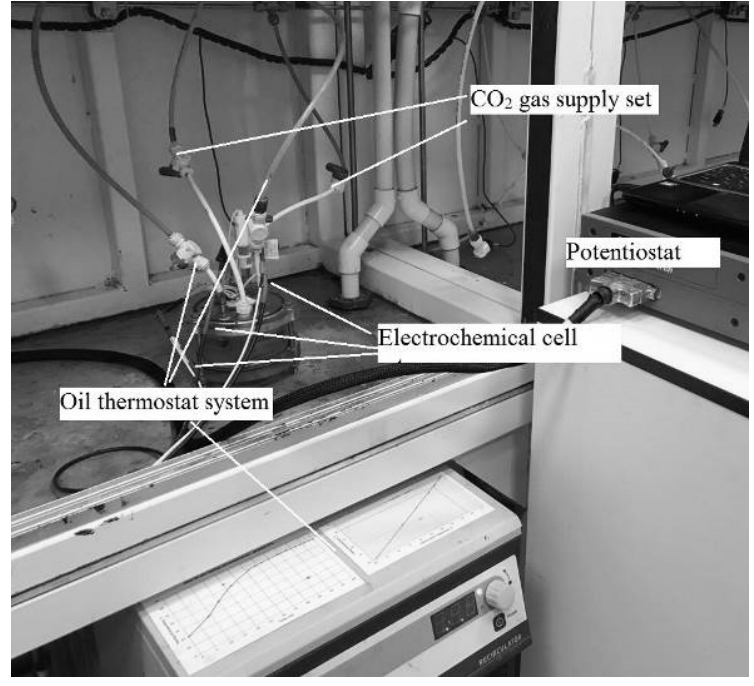

Fig. 2. External view of corrosion electrochemical tests setup

Electrochemical corrosion tests were consisted of open circuit potential (OCP) measurements and potentiodynamic polarization with $0.16 \mathrm{mV} / \mathrm{s}$ scan rate in range of $\mathrm{OCP} \pm 50 \mathrm{mV}$ with followed corrosion rates (CR) calculations according to Tafel corrosion current $\left(i_{\text {corr }}\right)$ extrapolation. Equivalent weights samples values were in range $27.99-28.14$ depending on actual steels chemistry. Materials density was set to $7.8 \mathrm{~g} / \mathrm{cm}^{3}$. Knowing specimen area, density, equivalent weight it was possible to calculate corrosion rates from corrosion current measurements results [5]. Graphic representation of electrochemical measurements procedure is shown in Fig. 3.

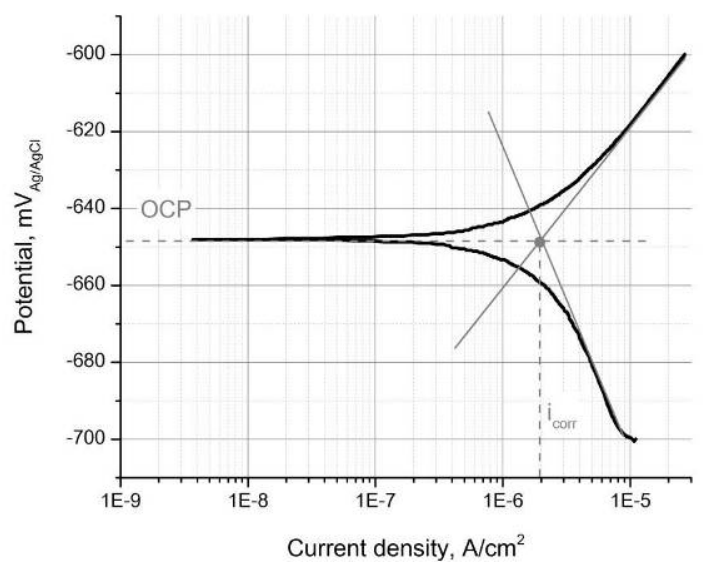

Fig. 3. Graphic representation of electrochemical tests measurements

OCP value corresponds to equilibrium corrosion potential and will be referred as potential in further discussion.

\subsection{Metallography}

Steel microstructure study was carried out with using light optical microscopy. Microstructures that were corresponded to transverse $1 / 4$ pipeline thickness were revealed by $4 \%$ Nital etching. Hardness measurements were performed by Vickers microhardness test with 180 g load. 


\section{Results and discussion}

Prior the electrochemical test results discussion microstructure investigation will be presented. Investigated steels microstructures are shown in Fig. 4.

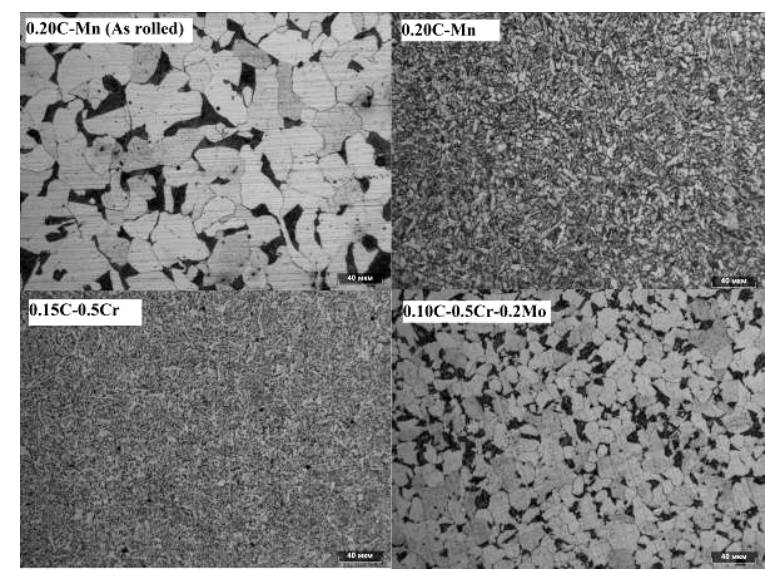

Fig. 4. Microstructures of investigated steels, $\times 200,4 \%$ Nital

$0.20 \mathrm{C}-\mathrm{Mn}$ (as-rolled) and 0.20C-0.5Cr-0.2Mo steels had ferrite-pearlitic microstructures with relative hardness values equal to 175 and $198 \mathrm{HV}$. The C-Mn (As rolled) steel had not banded slightly coarse microstructure in comparison with $0.20 \mathrm{C}-0.5 \mathrm{Cr}-0.2 \mathrm{Mo}$ steel that have fine, but not homogeneous structure which is characterized by perlite and ferrite phase distribution. This type of inhomogeneity could be formed during annealing heat treatment and solidification inheritance phenomena occurrence [6,7]. The $0.20 \mathrm{C}-\mathrm{Mn}$ steel microstructure investigation revealed fine distributed ferrite and pearlite phases. The revealed microstructure hardness is equal to $186 \mathrm{HV}$. The microstructure of $0.15 \mathrm{C}-0.5 \mathrm{Cr}$ steel is spheroidized annealed microstructure with uniform carbides distribution in ferrite matrix. The hardness was equal to $184 \mathrm{HV}$. So, as overall investigation it could be concluded that investigated steels are belong to similar strength grade, but with different microstructure conditions as the result of production route technology. The microstructure investigation will be used in electrochemical corrosion tests results interpretation.

As the results of electrochemical tests polarization curves for investigated steels in different environments were obtained and analyzed. For example, 0.20C-Mn steel polarization curves evolution depending on temperature and solution $\mathrm{pH}$ is presented in Fig. 5.

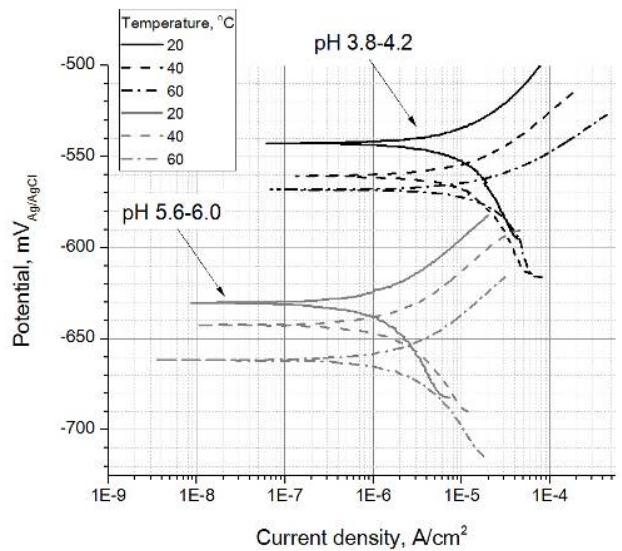

Fig. 5. 0.20C-Mn steel polarization curves evolution depending on temperature and solution $\mathrm{pH}$

According to Fig.5 lower $\mathrm{pH}$ in non-buffered $\mathrm{CO}_{2}$ saturated solution shifts $\mathrm{OCP}$ from $\approx 650 \mathrm{mV}$ range to $\approx 550 \mathrm{mV}$ with following increasing of cathodic and anodic reactions current densities. This fact is agreed with results of $\mathrm{CO}_{2}$ electrochemistry study [8]. Also, the possible explanation of observed polarization curves shifts is cathodic reaction evolution due carbonic acid dissociation dependence on $\mathrm{pH}$. The overall electrochemical corrosion tests results are presented in Table 3.

Table 3. Electrochemical corrosion test results

\begin{tabular}{|c|c|c|c|c|c|}
\hline \multirow{3}{*}{ Steel } & \multirow{2}{*}{$\begin{array}{c}\text { Temperature, } \\
{ }^{\circ} \mathrm{C}\end{array}$} & \multicolumn{2}{|c|}{$\mathrm{pH} 5.6-6$} & \multicolumn{2}{c|}{$\mathrm{pH} 3.8-4.2$} \\
\cline { 2 - 6 } & $\begin{array}{c}\mathrm{OCP}, \\
\mathrm{mV}\end{array}$ & $\begin{array}{c}\mathrm{CR}, \\
\mathrm{mm} / \mathrm{y}\end{array}$ & $\begin{array}{c}\mathrm{OCP}, \\
\mathrm{mV}\end{array}$ & $\begin{array}{c}\mathrm{CR}, \\
\mathrm{mm} / \mathrm{y}\end{array}$ \\
\hline \multirow{2}{*}{$\begin{array}{c}0.20 \mathrm{C}-\mathrm{Mn} \\
\text { (As rolled) }\end{array}$} & 20 & -627 & 0.03 & -562 & 0.33 \\
\cline { 2 - 6 } & 40 & -641 & 0.08 & -577 & 1.25 \\
\hline \multirow{3}{*}{$0.20 \mathrm{C}-\mathrm{Mn}$} & 60 & -660 & 0.13 & -588 & 1.71 \\
\cline { 2 - 6 } & 20 & -632 & 0.02 & -543 & 0.26 \\
\cline { 2 - 6 } & 40 & -640 & 0.04 & -564 & 0.61 \\
\hline \multirow{2}{*}{$0.15 \mathrm{C}-$} & 60 & -664 & 0.05 & -570 & 0.79 \\
\cline { 2 - 6 } $0.5 \mathrm{Cr}$ & 20 & -652 & 0.06 & -571 & 0.74 \\
\cline { 2 - 6 } & 40 & -662 & 0.10 & -585 & 1.43 \\
\hline $0.10 \mathrm{C}-$ & 60 & -677 & 0.13 & -587 & 2.14 \\
\cline { 2 - 6 } $0.5 \mathrm{Cr}-$ & 20 & -664 & 0.02 & -541 & 0.36 \\
\cline { 2 - 6 } $0.2 \mathrm{Mo}$ & 40 & -677 & 0.04 & -556 & 0.77 \\
\cline { 2 - 6 } & 60 & -682 & 0.07 & -567 & 1.29 \\
\hline
\end{tabular}

According to electrochemical results (Table 3 ) the OCP from -682 to -627 were observed in solution with higher $\mathrm{pH}$ 5.6-6.0 and from -588 to -541 in non-buffered $\mathrm{CO}_{2}$ saturated solution with lower $\mathrm{pH} 3.8-4.2$. The corrosion rates measurements results showed following variation: $0.02 \div 0.13 \mathrm{~mm} / \mathrm{y}$ at $\mathrm{pH} 5.6-6.0$ and $0.26 \div 2.14 \mathrm{~mm} / \mathrm{y}$ at $\mathrm{pH} 3.8-4.2$, where increased rates correspond to increased environment testing temperature. Graphical comparative representation of obtained data (Table 3 ) is presented in Figures 6 and 7. 


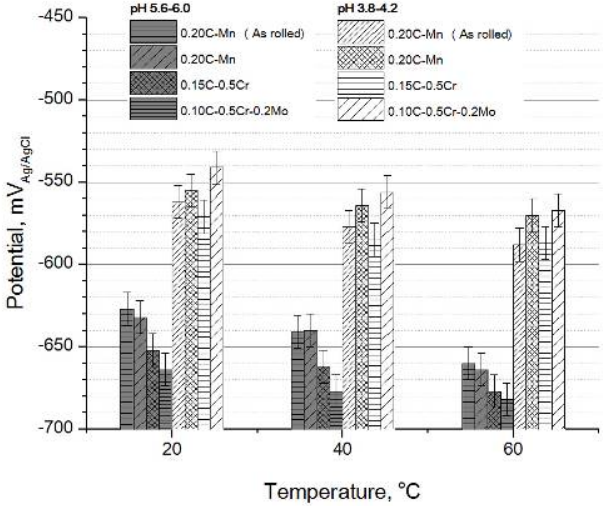

Fig. 6. Investigated steels potentials comparison depending on $\mathrm{pH}$ and temperature

From corrosion rates point of view steels could be ranged in following order from poor to best corrosion performance in $\mathrm{CO}_{2}$ environment: $0.15 \mathrm{C}-0.5 \mathrm{Cr}, 0.20 \mathrm{C}$ $\mathrm{Mn}$ (As rolled), 0.10C-0.5Cr-0.2Mo, 0.20C-Mn. In purpose of additional illustrations for this type of steel comparison Figures 8 and 9 are presented below.

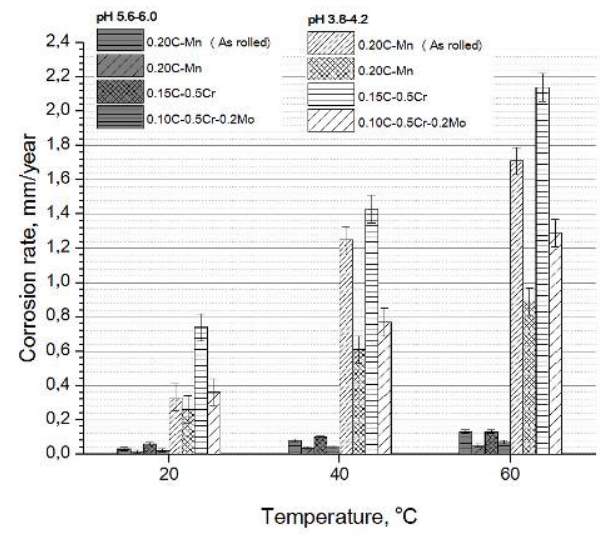

Fig. 7. Investigated steels corrosion rates in $\mathrm{CO}_{2}$ environment depending on $\mathrm{pH}$ and temperature

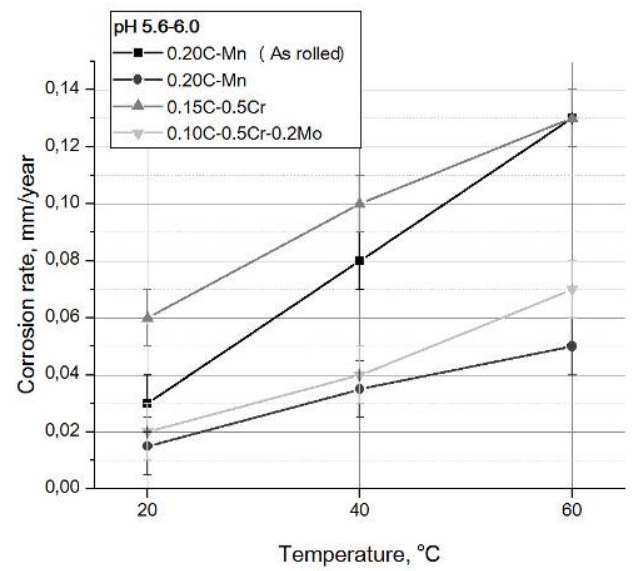

Fig. 8. Temperature influence on investigated steels corrosion rates in $\mathrm{CO}_{2}$ environment with $\mathrm{pH}$ range 5.6-6.0

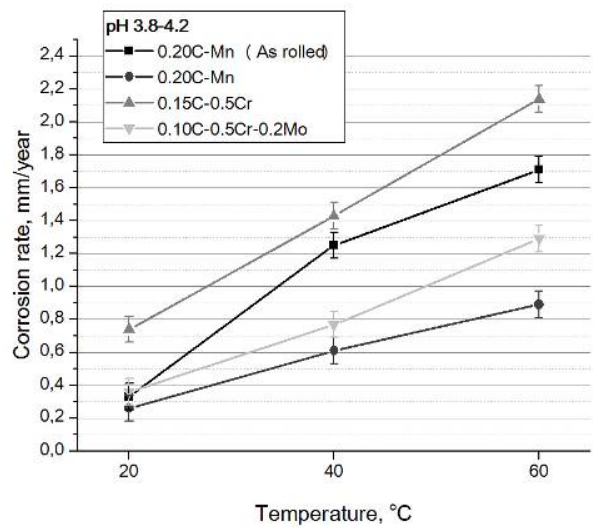

Fig. 9. Temperature influence on investigated steels corrosion rates in $\mathrm{CO}_{2}$ environment with $\mathrm{pH}$ range 3.8-4.2

Overall analysis environment parameters influence has shown that by increasing temperature from 20 to $60^{\circ} \mathrm{C}$ and by decreasing $\mathrm{pH}$ from $\approx 6.0$ to $\approx 4.0$ corrosion rates were dramatically increased. The interpretation for this experimentally obtained fact is complex microstructure/chemistry effect and its interaction with environment.

Corrosion rates measurements results show that there was no benefit in $0.5 \mathrm{Cr}$ addition for $0.15 \mathrm{C}-0.5 \mathrm{Cr}$ steel as the result of high carbon content chromium was tied up in carbides and then was no more available to reduce corrosion rate.

The next $0.20 \mathrm{C}-\mathrm{Mn}$ (As-rolled) is slightly better in comparison with previous example $(0.15 \mathrm{C}-0.5 \mathrm{Cr})$, due to ferrite-perlite microstructure after hot rolling process. The $0.10 \mathrm{C}-0.5 \mathrm{Cr}-0.2 \mathrm{Mo}$ has shown good performance and it is due to ferrite-perlite microstructure and alloying system but revealed ferrite-perlite microstructure inhomogeneity did not let get $\mathrm{CO}_{2}$ corrosion benefit from $\mathrm{Cr}$ and $\mathrm{Mo}$ additional alloying. The $0.20 \mathrm{C}-\mathrm{Mn}$ steel with relatively low sulphur content (Table 1) in comparison with as-rolled $0.20 \mathrm{C}-\mathrm{Mn}$ steel and which is had fine well distributed ferrite-perlite microstructure has shown best performance in $\mathrm{CO}_{2}$ containing environment. It should be noticed that obtained data is more likely corresponds to steel-environment interaction in instantaneous context and it didn't cover a complex topic of $\mathrm{CO}_{2}$ corrosion products layer formation in time. There was published data [9] that the more uniform the distribution and the smaller the ferrite grain size, the lower the corrosion rate.

\section{Conclusions}

1. The corrosion and metallography studies of commercially available pipeline steels were provided. It was shown that $0.20 \mathrm{C}-\mathrm{Mn}$ steel with fine homogenous microstructure had relatively lowest corrosion rates in $\mathrm{CO}_{2}$ environment.

2. There is no clear evidence benefit significant influence of $\mathrm{Cr}$ and Mo addition on corrosion rates. The most possible reason is microstructure condition. For example, the $0.15 \mathrm{C}-0.5 \mathrm{Cr}$ steel in spheroidized microstructure condition have 
relatively high corrosion rates in comparison with $0.20 \mathrm{C}-\mathrm{Mn}$ steels.

3. According to investigated environments conditions, the temperature increasing and $\mathrm{pH}$ decreasing leads to steels corrosion rates increasing in $\mathrm{CO}_{2}$ saturated environment.

\section{References}

1. M.B. Kermani, A. Morshed, Corrosion - Vol.59, no.8 (2003)

2. M. Ueda, H. Takabe, P.I. Nice, CORROSION 2000, NACE International 2000

3. T. Muraki, T. Hara, K. Nose, H. Asahi, CORROSION 2002, paper no. 272 (Houston, TX: NACE, 2002)

4. Y.S. Choi, S. Nešic, H.G. Jung, Corrosion - Vol.59, №8 (2003)

5. ASTM G102-89 (2015) e1., Standard Practice for Calculation of Corrosion Rates and Related Information from Electrochemical Measurements, ASTM International, West Conshohocken, PA, 2015, www.astm.org

6. Krauss, G, Solidification, Segregation, and Banding in Carbon and Alloy Steels, Metallurgical and Materials Transactions B: Process Metallurgy and Materials Processing Science, Volume 34, Issue 6, December 2003, Pages 781-792

7. Kazakov, A., Daniil Kiselev, Elena Kazakova, George F. Vander Voort, and Lev Chigintsev. "Quantitative Description of Microstructural Banding in Steels." Materials Performance and Characterization 6, no. 3 (2017): 224-236. doi: https://doi.org/10.1520/MPC20160009

8. Aria Kahyarian, Bruce Brown, Srdjan Nesic, Electrochemistry of $\mathrm{CO}_{2}$ corrosion of mild steel: Effect of $\mathrm{CO}_{2}$ on iron dissolution reaction, Corrosion Science, Volume 129, 2017, Pages 146151

9. Guenter, S., Hörstemeier, M., Fundamental aspects of $\mathrm{CO}_{2}$ metal loss corrosion - Part II Influence of different parameters on $\mathrm{CO}_{2}$ corrosion mechanisms, Paper 06112, CORROSION/2006, NACE International, 2006 